\title{
Former Yugoslav Republic of Macedonia: Report on Observance of Standards and Codes-Fiscal Transparency Module
}

This Report on the Observance of Standards and Codes on Fiscal Transparency for the Former Yugoslav Republic of Macedonia was prepared by a staff team of the International Monetary Fund as background documentation for the periodic consultation with the member country. It is based on the information available at the time it was completed on July 12, 2006. The views expressed in this document are those of the staff team and do not necessarily reflect the views of the government of the Former Yugoslav Republic of Macedonia or the Executive Board of the IMF.

The policy of publication of staff reports and other documents by the IMF allows for the deletion of market-sensitive information.

To assist the IMF in evaluating the publication policy, reader comments are invited and may be sent by e-mail to publicationpolicy@imf.org.

Copies of this report are available to the public from

International Monetary Fund • Publication Services

700 19th Street, N.W. • Washington, D.C. 20431

Telephone: (202) 6237430 • Telefax: (202) 6237201

E-mail: publications@imf.org • Internet: http://www.imf.org

Price: $\$ 15.00$ a copy

\section{International Monetary Fund} Washington, D.C. 

INTERNATIONAL MONETARY FUND

\title{
FORMER YUGOSLAV REPUBLIC OF MACEDONIA \\ Report on the Observance of Standards and Codes (ROSC) Fiscal Transparency Module
}

\author{
Prepared by the Fiscal Affairs Department
}

Approved by Susan Schadler and Peter S. Heller

July 12,2006

\section{EXECUTIVE SUMMARY}

This report provides an assessment of fiscal transparency practices in FYR Macedonia in relation to the requirements of the IMF Code of Good Practices on Fiscal Transparency based on discussions with the authorities and other organizations, the authorities' response to the IMF fiscal transparency questionnaire, and other sources of information. The IMF Manual on Fiscal Transparency (http://www.imf.org/external/np/fad/trans/manual/) should be consulted for further explanation of the terms and concepts discussed in this report.

FYR Macedonia meets the requirements of the fiscal transparency code in several key areas: (i) the allocation of responsibilities among different levels of government is well defined, but the ongoing fiscal decentralization process, particularly related to the devolution of expenditure responsibilities to local governments and borrowing by local governments, must be carefully monitored and underpinned by improved capacity at the local level; (ii) the central bank has operational independence from the government and is barred from financing it; (iii) information on public and publicly-guaranteed debt is regularly published; (iv) the legal framework for the management of public funds is clear and comprehensive with regard to the budget process and responsibilities; (v) the annual budget process is transparent, and the budget presentation is rapidly moving toward international good practice; (vi) the budget preparation has a strategic phase, where the main parameters for fiscal policy are determined and indicative ceilings for expenditure areas are set; (vii) the introduction of program budgeting with the 2005 budget (together with a description of programs in the budget document) has provided much better transparency of expenditure plans; (viii) the treasury accounting system is capable of producing accurate and frequent in-year reports on central government budget outturns; (ix) extrabudgetary funds and local governments have been integrated into the treasury single account; (x) the legislative basis for taxation is generally clear and comprehensive, and legislation in the areas of the value-added tax and customs duties are being harmonized with EU practices; (xi) tax administration officials are given legal protection from political interference; and (xii) the state audit office, which conducts external audit, is independent from the executive branch and its mandate covers all public sector activities.

However, fiscal transparency in FYR Macedonia could be improved in several respects, including through: (i) the provision in budget documents of public debt sustainability analysis and information on fiscal risks, contingent liabilities, and tax expenditure; (ii) strengthened reporting on state-owned enterprises and a more transparent nomination process for board members of state-owned enterprises, funds, and agencies; (iii) the provision in the budget memorandum of an overview of new expenditure initiatives, and the development of a system for tracking their expenditure implications; (iv) further support to the recently-established internal audit units; and (v) increased funding for the activities as well as improved follow-up on the recommendations of the state audit office. 


\section{CONTENTS}

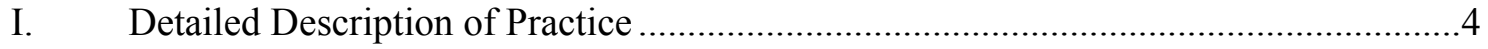

A. Clarity of Roles and Responsibilities........................................................

B. Open Budget Preparation, Execution, and Reporting ....................................15

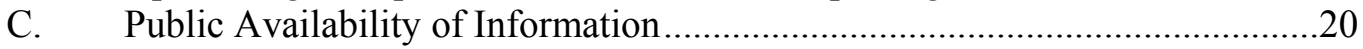

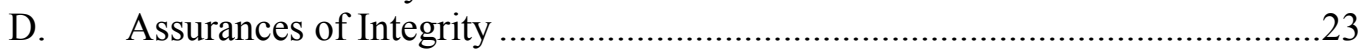

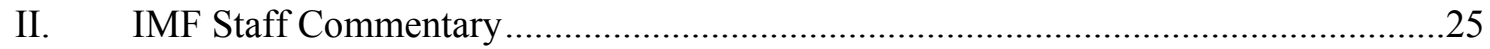

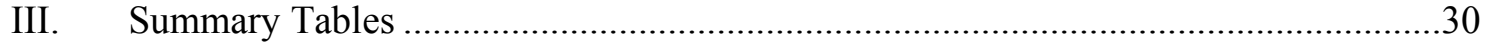

Tables

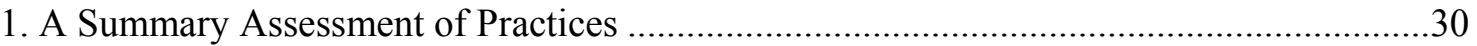

\section{Boxes}

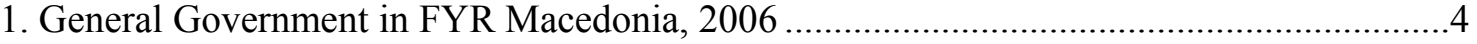

2. Privatization Process of the Electric Power Company of FYR Macedonia.......................... 7

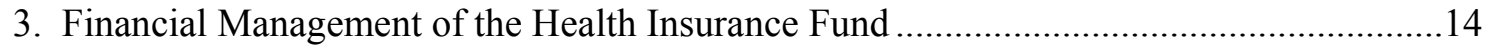

4. The Budget Preparation Process in FYR Macedonia ....................................................15 


ABBREVIATIONS
Central Internal Audit
Civil Service Agency
Extrabudgetary Funds
Energy Regulatory Commission
General Data Dissemination System
Government Finance Statistics
Health Insurance Fund
International Federation of Accountants
International Monetary Fund
International Association of Supreme Audit Offices
Macedonian Integrated Customs Information System
Macedonian Bank for Development Promotion
Ministry of Finance
National Bank Council
National Bank of the Republic of Macedonia
Pension and Disability Fund
Public Debt Management Department
Public Debt Management Strategy
Public Investment Program
Public-Private Partnerships
Public Revenue Office
Reports on the Observance of Standards and Codes
State Audit Office
State-Owned Enterprises
Special Revenue Accounts
State Statistical Office
Transparency International Macedonia
Treasury Single Account




\section{Detailed Description Of Practice ${ }^{1}$}

\section{A. Clarity of Roles and Responsibilities}

\section{Definition of Government Activities}

\section{The general government is defined consistently with Government Finance} Statistics (GFS) principles, and is well covered in the budget process. The units of the general government are listed in Box 1 . Government activities are clearly distinguished from those of financial and nonfinancial corporations and all central government fiscal activity is included in the budget and fiscal reports, ${ }^{2}$ although the quality of the information on the so-called special revenue accounts needs to be improved. ${ }^{3}$ Four major extrabudgetary funds (EBFs) have own revenue and expenditure capabilities. ${ }^{4}$ The activities of these funds are

\begin{tabular}{|c|c|c|}
\hline Box 1. General Government in FYR Macedonia, 2006 & \multicolumn{2}{|c|}{$\begin{array}{c}\text { Percent of } \\
\text { GDP }\end{array}$} \\
\hline \multicolumn{3}{|l|}{ General government in FYR Macedonia comprises the following: } \\
\hline \multicolumn{3}{|l|}{ Central Government Units Covered by the Budget } \\
\hline 1. General public services, incl. parliament, president's office, judiciary, and ministries. & & 17.5 \\
\hline \multicolumn{3}{|l|}{ Central Government Units with Individual Budgets* } \\
\hline 2. Extrabudgetary funds & $(19.8)$ & 12.1 \\
\hline 2.1 Pension and disability fund & $(10.7)$ & 7.1 \\
\hline 2.2 Health insurance fund & $(5.4)$ & 3.4 \\
\hline 2.3 Road fund & $(1.5)$ & 1.1 \\
\hline 2.4 Employment agency & $(2.2)$ & 0.5 \\
\hline \multicolumn{3}{|l|}{ Local Governments } \\
\hline 3. Local and Municipal Government & & 3.7 \\
\hline
\end{tabular}

\footnotetext{
${ }^{1}$ Discussions on fiscal transparency were held in Skopje during March 11-24, 2005, and the final report was updated based on information available as of end-May 2006. The staff team, comprising Messrs. Baig, van Eden, and Velloso (all FAD), was supported by the IMF resident representative office in FYR Macedonia. The team met with Deputy Prime Ministers Jordanov and Xhaferri, Finance Minister Popovski, National Bank Governor Goshev, Economy Minister Besimi, Local Self-Government Minister Sulejmani, the Budget Commission of Parliament, and other officials from various government ministries and departments, as well as officials from the city of Skopje and representatives of state-owned enterprises, donors, and NGOs.

${ }^{2}$ Decentralization is being implemented under the Ohrid Peace Framework Agreement of 2001. The Law on Local Self-Government and other legislation relating to fiscal decentralization make a clear distinction between central government and local government authorizations.

${ }^{3}$ While the budget documents include projected revenue and expenditure related to over sixty special revenue accounts, the rules for the collection of fees that go into those accounts are not readily available in the documents. In addition, revenue accruing to the special revenue accounts suffers from double-counting, as the treasury cannot eliminate transactions between different special revenue accounts.

${ }^{4}$ These are the Pension and Disability Fund (PDF), the Health Insurance Fund (HIF), the Road Fund, and the Employment Agency.
} 
described in the budget documents and reports. The definition of government activities is consistent between the ministry of finance (MOF) and the central bank, the National Bank of the Republic of Macedonia (NBRM).

\section{The relationship between the government and state-owned enterprises} (SOEs) is well defined in law, but reporting on as well as management and supervision of SOEs could be strengthened. The legal basis for the relation of the government with SOEs is the Public Enterprises Law. While this Law provides a number of safeguards for the prudent management of state assets, including the transfer of profits, reporting to the general public and parliament on state asset holdings needs to be substantially improved. For example, overall policy objectives of the government and the specific stance toward individual SOEs need to be clearly presented. The status of SOEs is different from private companies in that they are established by an Act of Establishment, the influence of government is protected (even if a majority of shares is sold), and SOE activities are limited by a statute. The responsibility for the management of state assets in both SOEs and equity holdings in privatized companies is shared by the MOF, the ministry of economy (in case of restructuring), and the sectoral ministry directly responsible for the area of activity of the SOE. However, this shared responsibility needs to be better defined in law and, perhaps, be centralized administratively within the MOF. The assignment on behalf of the government of members to management and/or supervisory boards is carried out by a committee of ministers and senior civil servants, but selection criteria for board members and reporting on their designation, including mandate, political affiliation (if any), and remuneration, are not currently required.

\section{The number of remaining SOEs is relatively small, and state equity holdings} in privatized enterprises are relatively limited. The number of SOEs has steadily declined as the privatization process draws close to an end. In total, 1,688 companies were privatized up to mid-2004 for an estimated value of approximately 132.6 billion denars. The privatization agency, which largely managed the privatization process, was closed at the end of March 2005. ${ }^{5}$ The intention of the government is to transfer all the remaining SOEs to the private sector. At end-2005, the central government still had majority shareholder positions in nine companies and minority positions in $27,{ }^{6}$ including full control of MEPSO, the electricity transmission operator, AD ELEM, which consists of all electricity generating assets, and AD TEC Negotino, the single oilpower plant in the country, as well as a 49 percent share in the telecom company. In March 2006, 90 percent of shares of AD ESM, the electricity distribution company, were sold to Austria's EvN for 225 million euros and the commitment to invest 96 million euros over three years. AD TEC Negotino has already been offered for sale and is expected to be sold soon, and AD ELEM is expected to be offered for sale next year. The value of the remaining state holdings in SOEs and privatized enterprises is

\footnotetext{
${ }^{5}$ In a few specific cases, where restructuring or liquidation of loss-making SOEs was needed, the privatization was handled by the ministry of economy and outside the usual privatization framework. While this practice was not necessarily good for transparency and uniformity of treatment, privatizations carried out in this fashion were conducted through open international tenders.

${ }^{6}$ In several instances, the government's minority shareholder position in privatized companies has been enhanced by the issuance of golden shares.
} 
estimated at 48 billion denars, or the equivalent to 18 percent of GDP. Quasi-fiscal activities of SOEs appear to be small. ${ }^{7}$ For example, electricity utility rates are controlled by the Energy Regulatory Commission (ERC), an independent body established in 2003, but social/sectoral objectives do not seem to be pursued through pricing. The banking system in FYR Macedonia is mostly (92 percent as of end-December 2005) in private hands. The state still wholly owns the capital of Macedonian Bank for Development Promotion (MBDP), which provides funds on favorable terms for certain export-oriented activities, and has one-third ownership stake of the Post Bank, which is uniquely positioned as it operates largely through the post office branches in the country.

\section{The legal and management framework for privatization is clearly defined in} law, but privatization processes in the past reportedly lacked transparency. The framework for privatization has been defined in the Law on Transformation of Enterprises with Social Capital and the Law on Privatization of State Capital. While this legal framework prescribes safeguards for transparency, such as public tenders, equal treatment of domestic and international bidders, and the use of preannounced selection criteria, the privatization of some SOEs has reportedly been subject to political pressure. ${ }^{8}$ The State Audit Office (SAO) has not been systematically involved in the auditing of individual privatizations. However, the government has recently taken several steps to enhance the transparency of the privatization of the electricity utility (Box 2).

\section{Laws and processes related to government regulation of the nonfinancial} private sector are generally clear, but implementation problems exist. In recent years, new laws have been introduced in a range of areas to harmonize with EU laws. These include laws in the areas of banking, company registration, property, bankruptcy, competition, securities, labor, energy, taxation, and telecoms. Efforts have been made to provide easy access to information concerning the rights and obligations of private sector participants, especially in the areas of company registration and taxation. The regulations are binding for the entire private sector. While the relevant laws and processes are generally sound, implementation of private sector regulation is perceived to have some shortcomings, and the enforcement of regulations by the judicial system is considered to be weak.

\footnotetext{
${ }^{7}$ The government has transferred part of its asset portfolio to the PDF to strengthen the balance sheet of the PDF. Individual share holdings are limited to 15 percent of capital and, in practice, the PDF acts as a silent investor.

${ }^{8}$ Transparency shortcomings in past privatization processes were mentioned to the staff team by Transparency International Macedonia and Foundation Open Society Institute Macedonia.
} 


\section{Box 2. Privatization Process of the Electric Power Company of FYR Macedonia}

The government of FYR Macedonia has begun the privatization of the state-owned electricity utility. The first major preparatory step was undertaken in 2004, when the electricity company was unbundled into two joint stock companies, the Operator of Transmission System of Macedonia (MEPSO) and the Electric Power Company of Macedonia (ESM). In September 2005, ESM was split into three independent legal entities, with separate supervisory and management boards, namely: (i) AD ESM, which owns and operates the electricity distribution assets; (ii) AD ELEM, which consists of all electricity generation assets; and (iii) AD TEC Negotino, the single oil-power plant in the country. The government successfully completed the privatization of AD ESM in March 2006 by selling a 90 percent stake to the Austrian EvN. AD TEC Negotino's international tender was launched in April 2006. While the government intends to continue owning MEPSO, the offering for sale of AD ELEM shares is planned for next year. MEINL Bank Consortium, a private consultant, has been hired for the restructuring and the preparation of the groundwork for the two-stage prequalification and bidding process. In order to facilitate the public availability of information during the process, the government signed a memorandum of understanding with Transparency International Macedonia (TIM). The government has pledged to work closely with TIM to make all the pertinent information available to the public in a timely manner. In addition, TIM has assisted the government in organizing public discussions on the benefits and potential drawbacks of the decision to privatize AD ESM as well as the timetable and eventual impact on the economy of the privatization of AD ESM. In this connection, TIM has trained the media on the technical aspects of the entire process (including international tendering standards and relevant local laws), hosted public awareness campaigns and roundtables to provide updates, and made available on the internet answers to frequently asked questions on this issue. In addition, the presence and deep involvement of the EBRD in the privatization process of AD ESM has increased significantly the transparency of this process.

\section{Government relations with the central bank and public financial sector}

\section{The central bank is operationally independent, and its financial relationship} with the government is mostly transparent. The NBRM Law details the framework of the nine-member National Bank Council (NBC), as well as the members' necessary qualifications, term limit, responsibilities, and disclosure requirements. Upon proposal of the president of FYR Macedonia, parliament appoints the governor and six other members of the NBRM Council for a seven-year term of office. And upon recommendation of the governor, parliament appoints three vice-governors (two of which are members of the NBC) also for a seven-year term of office. The NBRM Law forbids the central bank to finance the government, ${ }^{9}$ and clearly spells out rules for transfers to the budget of central bank profits. Prior to 2004, the NBRM paid interest on government deposits held at the central bank, and interest payments were generally defined on commercial terms. ${ }^{10}$ However, the NBRM unilaterally stopped paying interest in 2004, when it became clear that the NBRM was going to report significant losses. The NBRM has recently been making interest

\footnotetext{
${ }^{9}$ Article 51 of the NBRM Law states that the central bank shall not extend loans and credits to the central government and government administration bodies, as well as not guarantee the assumed liabilities of the bodies and not purchase directly their debt instruments.

${ }^{10}$ Typically, the MOF and the NBRM reached an annual agreement on the interest rate on government deposits. The NBRM Law does not explicitly make provisions for interest payments on government deposits, although the law does require that interest is paid on securities issued to cover NBRM losses.
} 
payments on government deposits, albeit at very low rates ( 0.7 percent per year on denar deposits, and 0.2 percent on foreign currency deposits). While the NBRM Law clearly stipulates how to deal with losses arising from central bank operations (first, through the general reserves, and then, if needed, through either direct budgetary transfers or the issuance of government securities), recent recapitalization needs have been subject to ad hoc amendments to the Law.

7. Public financial corporations carry out limited quasi-fiscal activities. The fully state-owned MBDP is geared toward supporting export-oriented activities, accounting for 1.6 percent of the assets and 4.5 percent of the capital of the banking sector. However, the MBDP does not take retail deposits and is instead financed by concessional loans from abroad and the budget. As noted above, the Post Bank is uniquely positioned as it operates largely through the post office branches in the country.

\section{Fiscal management relations among the branches of government}

\section{The fiscal roles of the executive, legislative, and judicial branches are clearly} defined in law. The Constitution of the Republic of Macedonia and the Organic Budget Law assign clearly distinct responsibilities in fiscal management for the executive and the legislature, while the judiciary is given budgetary autonomy. The constitution provides for the separation of powers between the three functions of government, giving the executive the tasks of budget preparation and execution, while the legislature approves the budget of the republic and determines taxes and fees. ${ }^{11}$ The judiciary is defined in the constitution as autonomous and independent, which has been interpreted to mean that it should determine its own budget without undue pressures from the executive branch. In practice, however, only the share of the judiciary's budget that is financed by court fees is determined independently from the other branches of government, and the MOF has considerable influence through the provision of supplementary funding. ${ }^{12}$ The budget of the judiciary is approved by parliament just as the central government budget and the budget of the EBFs. The Organic Budget Law describes the roles, responsibilities, main tasks, and key events of the budget process of the central and local governments. In this connection, the MOF is assigned a number of specific tasks, including the coordination and management of both preparation and execution of the budget on behalf of the government.

\section{Fiscal management relations among different levels of government}

9. The responsibilities of the different levels of government are determined through the Constitution and further specified through the Ohrid Peace Framework Agreement and the subsequent decentralization process laws. The Law on Local SelfGovernment and the Law on Local Self-Government Finance have been enacted in 2002 and 2004, respectively. They identify the areas of expenditure responsibility, and the tax

\footnotetext{
${ }^{11}$ See Articles 68 and 91 of the Constitution.

${ }^{12}$ Such deviations from the letter of the constitution are not uncommon. For example, municipalities in most countries are financially autonomous but, in practice, bound by central government in numerous ways. The issue is whether the present situation provides for adequate checks and balances. The influence of the MOF should be guided by cost-effectiveness considerations, and the overall control by parliament by ensuring independence from undue pressures.
} 
assignments and revenue sharing arrangements of local governments, which in FYR Macedonia are autonomous bodies, with an elected mayor (and his administration) designated as the executive and the municipal council as the local legislative body. A supervisory role has been assigned to the State Audit Office (SAO), which is responsible for auditing the financial administration of local governments. Ministers responsible for certain functional areas have been given coordinating and supervisory tasks (in their area of competence and according to the law) on municipal activities.

10. With the legal basis defined and the first municipal elections recently held, decentralization will include eventually a sizeable transfer of expenditure responsibilities to local governments. Municipal boundaries were redrawn in 2004, to better reflect local preferences of association, and municipal elections were held in March 2005. Given the political complexities of the decentralization process, only a few specific tasks have so far been transferred to local governments. Nonetheless, the areas where municipal competencies will be increased include public services, urban and rural planning, environmental protection, local economic development, culture, local finances, education, social welfare, health care, fire protection, sports, and recreation. The devolution of expenditure responsibilities to local governments must be carefully monitored, should lead to offsetting reductions in budgetary allocations to line ministries, and must be underpinned by improved capacity at the local level. In this latter regard, the central government has taken the initial steps (together with international donors and the Macedonian Association of Municipalities) of training staff and providing equipment in the critical area of public financial administration.

11. Increased expenditure responsibilities at the local level will be accompanied by higher revenue through enhanced tax autonomy and revenue sharing arrangements. Given the planned phased transfer of expenditure responsibilities, assigned income seems adequate for the initial phase of decentralization. Municipalities currently receive a 3 percent share of the VAT and of the personal income tax and have been given responsibility for the collection of municipal taxes which, until recently, were collected by the center on their behalf. The shift of responsibility for the collection of municipal taxes (e.g., property tax, property transfer tax, and inheritance tax) to municipal governments will create incentives for more effective and transparent collection efforts. In addition, when more expenditure responsibilities are shifted later on in the decentralization process, it will be important to monitor whether the revenue base of municipalities remains adequate, not only in aggregate but also over richer and poorer municipalities. In this respect, the so-called municipal equalization grant should be carefully monitored. The government has already adopted a stable formula for VAT revenue sharing based on the population, geographical area, and the number of settlements of each municipality. ${ }^{13}$ Two percent of the municipal share of VAT receipts were assigned to a reserve fund, to be available to municipalities unable to meet their expenditure obligations.

\footnotetext{
${ }^{13}$ For instance, the capital and largest city, Skopje, received 10 percent of the total and, of this, 40 percent was assigned to the metropolitan government and 60 percent to the ten municipalities that comprise Skopje on the basis of their population (60 percent), geographical area (27 percent) and the number of settlements on each municipality (13 percent).
} 
12. Municipalities will be able to borrow but with reasonably strict safeguards. Currently, borrowing by municipalities is restricted to within-year borrowing from the central government for cash management purposes. Under the Law on Local SelfGovernment Finance, municipalities will be able to borrow long-term for investment and short-term for cash-flow management. However, limitations will apply to the outstanding debt stock and debt service for long-term borrowing, as well as to the amounts to be borrowed short-term. Other limitations will apply, including that borrowing must be, in principle, in local currency, from the domestic capital market, and according to a stable or declining annuity repayment schedule. Foreign borrowing by municipalities not only will require a decision by the Municipality Council but also a separate law by parliament, further increasing control and transparency. Municipal borrowing will begin only after municipalities report continuously to the MOF on their financial situation and are free of arrears (both for 24 months). Municipalities have significant outstanding arrears at the moment. ${ }^{14}$ But, in the context of decentralization effort, the central government is working on an arrears clean-up plan, to set municipalities on a track to a sound financial position. $^{15}$

\section{The legal and administrative framework for budget management}

\section{The legal framework for management of public funds is clear and} comprehensive with regard to the budget process and responsibilities; accountability and transparency requirements are in the process of being strengthened. The Organic Budget Law, the so-called Law on Budgets, incorporates important principles of public finance: (i) the use of public funds requires approval by law; (ii) the budget is comprehensive, covering expenditure of all parts of the central government;

(iii) expenditure and revenue are presented and reported on a gross basis; (iv) budget managers are held accountable for the appropriate use of expenditure and revenue; and (v) the final account of government requires auditing by the SAO. The Organic Budget Law describes in detail the process of budget preparation and execution. The budget document, which is sent to parliament by end-November, contains the Budget of the Republic of Macedonia (presenting the expenditure of the central government) and the budget of the four EBFs, which are considered extrabudgetary because of their earmarked revenue and their legal constitution. The MOF has coordination and management roles in the budget preparation and execution of the EBFs similar, but at somewhat more arms length, to those for the central government budget users (i.e., line ministries, agencies, and offices of the central government). The budgets of the EBFs are approved by the government and parliament. The MOF's role in the budget process, particularly in the case of budget users, is very strong. For example, all explanatory texts are prepared by the MOF using inputs from the budget users. The Organic Budget Law also describes the basic budgetary processes and procedures for local governments, although these are described more in detail in the Law on Local Self-Government Finance.

\footnotetext{
${ }^{14}$ At end-2004, the total amount of arrears of municipalities was 3.1 billion denars, or the equivalent to around 1 percent of GDP, of which about two-thirds was owned to construction companies.

${ }^{15}$ An arrears settlement plan was adopted by the government in July 2005. The MOF has already contacted all municipalities to ascertain their level of arrears and, in the case of the larger municipalities, agreements have been reached with creditors on the settlement of outstanding liabilities. SOEs wrote off all claims due to interest arrears and reached agreements deferring the payment of principal arrears. As a result of these action, the total amount of arrears was halved by end- 2005 .
} 
14. The new Organic Budget Law was passed by parliament in July 2005, incorporating the reforms implemented for the first time with the 2005 budget; some of these reforms have been instrumental to improving transparency. Recent budget reforms include: (i) structuring the appropriations in the budget according to programs; (ii) defining better the content of the government's fiscal strategy paper; (iii) setting early expenditure limits in the budget process; and (iv) increasing the powers of the MOF to approve changes in expenditure within line ministry programs. The introduction of program budgeting (with accompanying description of programs in the budget document) has provided much better transparency of the government expenditure plans.

\section{Debt management and incurrence at the central government level are} assigned as the sole responsibility of the MOF. The new Public Debt Law, which was enacted by parliament on July 22, 2005, defines public debt, stipulates the allowed reasons for incurrence, the manner and procedure for issuance, as well as management and reporting requirements. The Law prescribes, inter alia, the preparation of a three-year Public Debt Management Strategy (PDMS), to be updated on an annual basis. The MOF will submit annual reports to parliament and semi-annual reports to the government on the implementation of the PDMS. The new Public Debt Law also regulates the issuance of government guarantees, and provides for the centralization of management, recording, and reporting on public debt at the MOF, where a new public debt management department (PDMD) has been set up since March 2005. ${ }^{16}$ The first PDMS covering the period 2006/08 was adopted by parliament on March 21, 2006. This strategy analyzes the risks of the debt portfolio, sets medium-term objectives, measures, and quantitative targets for the public and publiclyguaranteed debt. Also, the MOF issued on March 13, 2006, guidelines on debt reporting that should be followed by all issuers of public debt; the first debt reports were received by end-April. An integrated public debt database is expected to be in place by early 2007 . An important fiduciary issue that is being improved both by the new Public Debt Law and the Law on Budgets is that the payment of interest and principal on public debt will have the character of a permanent appropriation. ${ }^{17}$ Public-private partnerships (PPPs) are currently not regulated in FYR Macedonia.

16. Capital and current expenditure have yet to be fully integrated. While the rolling three-year public investment program (PIP) is prepared at the macroeconomic policy analysis department of the MOF, the PIP seems to lack sectoral prioritization and have limited links to the budget process. The latter might also be related to the late completion of the PIP (March of the first year for which the PIP applies). In addition, the program-budgeting initiative of the MOF's budget department seems to have incorporated a separate capital investment selection process that, at present, lacks a medium-term focus. More resources should be devoted to the PIP process, which should include a better

\footnotetext{
${ }^{16}$ Up to enactment of the new Public Debt Law, the management and recording of external public debt was handled by the NBRM, while the debt management unit of the MOF kept records of the domestic central government debt, but not on the debt of public enterprises and municipalities. And the cash management unit was part of the Treasury and responsible for liquidity management by smoothing out expenditure (in line with revenue forecast).

${ }^{17}$ The payment of obligations to foreign and domestic creditors has always been a priority in the State Budget even though no formal stipulation of permanent appropriation existed prior to the approval of the new Organic Budget Law.
} 
prioritization of projects. In addition, the PIP should be pulled forward so that it could play a more substantive role in the budget process. Moreover, both in the PIP process and in the yearly budget cycle, capital expenditure planning should incorporate supporting current expenditure needs over the medium term. A basic check on the adequacy of current resources to support capital investment seems to be lacking, in particular for grant-financed investments. Externally funded capital projects implemented through central government agencies and line ministries are included in the budget. ${ }^{18}$

\section{Mechanisms for the coordination and management of budgetary and} extrabudgetary activities are defined, but could be clarified further. EBFs have expenditure mandates and revenue bases defined by their respective laws, which also require them to submit and execute balanced budgets. The governance structure of the EBFs is also defined in law, and provides the government with ample scope to influence their operations through supervisory boards and specific ministerial approvals. The proper functioning of the EBFs depends on mutual respect for the obligations defined in law. For example, the imposition of constraints on contributions for fiscal policy reasons, which might be inconsistent with their spending obligations, can pose significant governance issues. On the other hand, more could be done within the present framework to require efficiency in the operations of the EBFs. These issues are magnified for the HIF, which is faced with health care providers with soft budget constraints not only due to weak management practices but also an open-ended mandate to provide health services (Box 3). This situation has given rise to significant arrears by the HIF, amounting to 987 million denars at end-2005, or the equivalent to about 0.4 percent of GDP. ${ }^{19}$ In 2006 , the government has taken several actions to put the health care system on a sounder financial footing, including the introduction of hard budget ceilings on health care institutions (based on their actual expenditure profile in 2003/05) and the placement of budget control officers in the 15 most indebted health care institutions. In addition, the MOF has placed a budget officer in the HIF, with the responsibility, inter alia, for exercising ex-ante control over expenditure commitments.

\section{The legal and administrative framework for tax policy and administration}

18. The legislative basis for taxation is generally clear and comprehensive. Four major categories of taxes are collected: (i) on income and profit tax (both personal and corporate); (ii) social security contributions (these comprise of contributions to the health insurance, pension and disability, and employment funds); (iii) on goods and services (VAT and excises); and (iv) on imports. ${ }^{20}$ The structure and complexity of the tax code is in line with European standards, and the tax law framework can be characterized as having reached a stable platform, although a number of policy changes have been made in recent years, including a reduction in the number of VAT exemptions. Profit tax

\footnotetext{
${ }^{18}$ Sometimes with the exception of the initial project year.

${ }^{19}$ Health care institutions had additional arrears to suppliers in the order of 1.8 billion denars at end-2005.

${ }^{20}$ The various taxes and contributions are collected by five agencies: the PRO (which is responsible for collecting domestic taxes), three social insurance funds (pensions, health, and unemployment contributions), and the customs department (taxes and duties at the border). In 2005, the administration of property taxes and other minor taxes, which were collected by the PRO, was devolved to the municipal governments.
} 
taxpayers are legal entities, residents and nonresidents of FYR Macedonia, which earn profit by carrying out activities in the country and abroad. Tax calculation is prepared on a prescribed form (tax balance), where the taxpayer presents the data and calculates the profit tax (method of self-declaration). According to the law, most individuals, i.e., those with salary or pension as the only source of income, are not required to file tax returns on a self-assessment basis. Rather, taxes are paid mostly through withholdings and determination of final liability by the Public Revenue Office (PRO). Usually, tax laws and procedural guidelines provide for consistent interpretation of taxpayers' liabilities and obligations, although administrative irregularities have been reported in a number of areas. In particular, a number of exemptions in the corporate tax and the uncertainties of the tax treatment for allowances in the personal income tax leave both taxes vulnerable to abuse.

\section{VAT and customs tax policies are increasingly being harmonized with EU}

standards. A good number of items, however, remains exempt from sales tax and customs duties, and others are subject to zero rating. There are also some exemptions in Law on the Personal Income Tax (PIT) that provide benefits for specific groups. The information on tax exemptions and holidays for individual tax payers are publicly available through the relevant tax laws and codes. Customs exemptions, for example, are listed and updated in the Customs Handbook, as well as posted on the Customs website. While tax expenditures are not systematically estimated, in recent years, during the budget process, the MOF has prepared a document analyzing the fiscal impact of the proposed changes in the tax law.

\section{Tax administration is clearly defined, but not well coordinated with overall}

fiscal management. The powers and limitations of tax officials to demand third party information and enforce collection of arrears are specified in laws and regulations. Tax administration is yet to be organized functionally, ${ }^{21}$ with each tax collecting body operating with their own functional units. A common taxpayer identification number (TIN) is used for all revenue departments and taxes. Other than the PRO and the customs, revenue agencies have limited or no enforcement capabilities. Legally, discretionary power is seldom allowed, but tax officials have been reported to exceed their authority in some cases. Guidelines for appeals and dispute resolution are clearly explained in the relevant tax codes. With respect to direct taxes, tax payers have the option of filing an appeal against the PRO's decision directly to the MOF within 15 days of receiving a tax liability determination. Appeals on customs decisions have to be filed within eight days of receiving the decision.

\footnotetext{
${ }^{21}$ The authorities have recently launched a major revenue administration reform program, with technical assistance from the Fund, to stregthen the collection of taxes and social insurance contributions. As part of the reform strategy, the headquarters of the PRO has been reorganized along functional lines and field offices will also be reorganized according to function during the next 12-18 months.
} 


\section{Box 3. Financial Management of the Health Insurance Fund}

The Health Insurance Fund (HIF) has been set up to manage the operation of universal and compulsory health care system based on the 1991 Health Care Law. Contributions provide more than 90 percent of the resources to the system; government transfers to the HIF and co-payments by patients are the main other sources of income. In 2004, expenditure through the HIF amounted to 15.7 billion denars, or roughly 5.6 percent of GDP. The HIF provides remuneration for health services for some 89 health care institutions, both public and private. However, about 70 percent of expenditure is channeled to five major public health care institutions in or near Skopje. The health care sector has been undergoing major organizational and administrative reforms for many years. The sector seems to be over-staffed and inefficient, and receives inadequate capital investment funds.

The reimbursement system of the HIF has been evolving over time. In the first instance, remuneration was based on the medical services provided. This was in line with a reform strategy aimed at making health care providers more entrepreneurial, as output-based remuneration would provide managerial flexibility in resource allocation. In practice, however, employment in health care providers has not been rationalized. Currently, the HIF lacks monitoring capabilities to verify effectively invoices of health care institutions and, reportedly, over-invoicing occurs regularly. At the same time, contribution levels of the HIF were set at levels that have made adequate levels of capital investment difficult to attain.

Under the guidance of the MOF and the Ministry of Health, the HIF has begun imposing input-based controls over expenditure of health care institutions. While some output-based invoicing remains, salaries, drugs and medical materials, and other essential operational costs are now remunerated directly from the HIF. However, the financial administration of health care institutions is very weak and audits are performed only irregularly. Health care institutions seem to work with open-ended budgets, implying that auditors lack a frame of reference.

The HIF is also implementing contractual agreements with health care institutions, specifying agreed upon outputs and supporting resources calculated on the basis of the number of patients in their district.

Incentives would be built into the system to dissuade unnecessary medical procedures.

The following measures would be instrumental to improving transparency and efficiency in the health care system:

- $\quad$ Strengthening of the input-based budgeting and monitoring systems by the HIF.

- $\quad$ Approval by the HIF of the budgets of health care institutions as well as the agreements on remedial actions on and sanctions due to excessive spending.

- $\quad$ Strengthening of the financial administration and internal audit functions in health care institutions through training and hiring of staff.

- $\quad$ Mandatory annual external financial and performance audits for health care institutions. Implementation of restructuring and rationalization programs involving, inter alia, staff reductions, closing of hospitals and clinics, and clearance of suppliers arrears.

21. Taxpayers' legal rights are clear. All relevant tax laws have clear administrative provisions for appeals. Two new laws enacted on April 1, 2006, the PRO Law and the Tax Procedure Law, have elaborated further on tax payers' rights and obligations.

\section{Public servants' code of behavior and anti-corruption activity}

\section{Public servants are subject to a code of behavior, but enforcement of the code} could be pursued with more vigor. Ethical standards of behavior for civil servants are laid out in the Code of Ethics of the Civil Servants. The code regulates the manner of conduct and operations of the civil servants in order to ensure recognition of the principles of legality, professional integrity, efficiency, and loyalty in performing their official duties. The code also regulates the implementation of these principles, and the civil servant is subject to disciplinary sanctions for any behavior against its provisions. 
Absent from the current framework is guidance for civil servants on conflict of interest issues, although financial conflict of interest is regulated by the Law on Civil Servants, which obliges civil servants to exclude any personal financial interests in the performance of his duties. SAO reports and independent accounts by TIM seem to indicate that prosecution of unlawful and sanctioning of unethical behavior by civil servants is not systematically and vigorously enforced.

\section{B. Open Budget Preparation, Execution, and Reporting}

The budget preparation process: clarity and consistency of process and presentation

23. The annual budget process is transparent and the presentation is rapidly moving toward international good practice. Box 4 indicates the main steps in the budget preparation process. The chart of accounts consists of an economic, functional, organizational, and program classification. The accounting system is cash-commitment based and does not incorporate accrual concepts yet. The economic classification is consistent with the GFS 2001 nomenclature. The budget classification, i.e., the classification used for determining appropriations, has the following layers: source of funding, budget user, program, sub-program, and economic line item.

\begin{tabular}{|l|l|l|}
\hline \multicolumn{3}{|c|}{ Box 4. The Budget Preparation Process in FYR Macedonia } \\
\hline \multicolumn{1}{|c|}{ Due dates } & \multicolumn{1}{c|}{ Activities } & Legal basis \\
\hline The fiscal year is set on a calendar-year basis by the Law on Budgets. The main steps are as follows: \\
\hline January/February & Projection of macroeconomic indicators by MOF & Law on Budgets \\
\hline End-March & Preparation and adoption of mid-term Fiscal Strategy document & Law on Budgets \\
\hline End-May & Establishment of indicative/hard expenditure ceilings* & Law on Budgets \\
\hline Mid-June & Budget Circular is sent to First Level Spending Units and EBFs & Law on Budgets \\
\hline Mid-August & Submission of proposed budget request to MOF & \\
\hline September & Analysis, discussion, and negotiation of requests & Law on Budgets \\
\hline $\begin{array}{l}\text { Late September/ } \\
\text { early October }\end{array}$ & $\begin{array}{l}\text { Revision of macroeconomic indicators and update of projected } \\
\text { revenue, expenditure, and fiscal balance }\end{array}$ & Law on Budgets \\
\hline $\begin{array}{l}\text { End-October } \\
\text { Budget proposal sent by MOF to government for approval }\end{array}$ & Law on Budgets \\
\hline Mid-November & Budget proposal sent to parliament for approval & \\
\hline End-December & Budget adopted by parliament and published in State Gazette & \\
\hline $\begin{array}{l}* \\
\text { Expenditure ceilings are indicative at this stage. In the Organic Budget Law, hard budget ceilings are set by } \\
\text { functional areas. }\end{array}$ &
\end{tabular}

The macroeconomic framework and policy basis for the budget

24. The overall balance of central government is the main indicator of the fiscal position in the budget, but the general government balance will be monitored from 2006 onward. The fiscal policy of the government is focused on signaling fiscal sustainability and prudence over the medium term and supporting the monetary policy of the NBRM as well as denar exchange rate stability in relation to the euro. Through the Treasury Single Account (TSA), the MOF can monitor, on a continuous basis, the cash balance of the central government, EBFs (since end-2004), and local governments (since mid-2005). Municipalities provide their final accounts to the MOF, which are then consolidated with those of the central government and the EBFs. As fiscal decentralization deepens, there is a strong case for timely monitoring of local government expenditure, revenue and, in the future, deficits as the decentralization reforms will gradually allow municipalities to borrow. This is the main reason why the MOF has 
incorporated municipalities into the TSA. However, it should be stressed that the TSA does not include reporting on receivables or payments due, neither of budget users nor of local governments. On borrowing, the MOF still needs to develop separate reporting guidelines.

\section{Budget forecasts and underlying macroeconomic assumptions are clearly presented both in the fiscal strategy document and in the annual budget.}

Macroeconomic forecasts are based on a consistent framework and clear assumptions about, for example, international indicators. The forecasts are not based on econometric models, but rather the result of trend analysis, proposed measures of economic policy, and the opinion of experts. Macroeconomic and fiscal projections, and their realization, are subject to regular monitoring and discussion with the International Monetary Fund (IMF) and the NBRM at key moments in the budget preparation and thereafter.

\section{Medium-term planning and analysis of fiscal risks}

26. While a statement on medium-term fiscal policy objectives is included in the budget document, fiscal sustainability issues and the impact on the fiscal balance of more adverse economic scenarios are not discussed. The fiscal strategy and the budget documents provide medium-term estimates at an aggregate level for revenue, expenditure, and the fiscal balance. The estimation methodology incorporates some key macroeconomic parameters, but does not take into account detailed estimates of the various cost drivers of expenditure. This means that the MOF is still some way away from introducing medium-term budgeting.

27. Fiscal rules apply only to EBFs and local governments. According to the Organic Budget Law, the EBFs are required to present a balanced budget, and local governments are currently required to balance their budgets according to the Law on Budgets. Also, as described above, the borrowing regime for local governments will be made more flexible in the coming years, but will remain subject to rules specified in the Law on Local Self-Government Finance. The central government is subject to process rules in that parliament can only propose budget amendments if compensatory savings are found elsewhere.

\section{Budget management is complicated somewhat by the widespread use of}

Special Revenue Accounts (SRAs). In 2004, there were 1,689 SRAs on which ministries or agencies received directly certain fees and charges for licenses or services rendered, as well as funds from foreign loans and donations used by the budget users. The use of these funds, which amounted to 7.8 billion denars in 2004, is earmarked to the ministry or agency involved in their collection. However, the collection of these funds is based on laws and regulations, both their intake and use are estimated in the budget documentation, and the SRAs (and transactions conducted through them) are integrated in the TSA. Nevertheless, this form of earmarking complicates the reallocation of budget priorities and, to some extent, diminishes the role of the budget.

\section{Estimates of new initiatives and ongoing costs of government policies are not} clearly distinguished in the budget documents. Until 2004, budget preparation was characterized by inadequate linkages of policies to expenditures and, given the organizational-economic budget classification, the budget was largely input based, making it difficult to identify and track policy initiatives and leading to considerable risk of unfunded mandates arising in the budget. The risk of unfunded mandates was in 
principle mitigated by the requirement in the Organic Budget Law that the financial implications of policy initiatives need to be assessed and their funding identified before consideration by the government. However, the MOF has not been systematically tracking approved policy initiatives.

30. Fiscal risks are not discussed with the budget. Contingent liabilities of the government are not discussed in much detail in the budget documents nor in the final account. Public debt outstanding is mentioned in those documents, but not discussed in any detail on issues such as maturity, currency composition, and type of instrument. However, there is a detailed discussion of these issues in the PDMS. More generally, the analysis of, and reporting on, public debt and guarantees are expected to improve considerably following the creation of the PDMD, which is also in charge of cash management.

\section{Clarity of control of budget execution}

31. Basic accounting and internal control procedures are in place, but the SAO reports on a number of discrepancies between treasury and budget users accounts. The central government's accounting framework and internal control procedures are described in the Law on Budget Institutions Accounting and Internal Control. The accounting system is a cash-commitment system, which is used both for the treasury's automatic payment system and budget users' accounting departments. The SAO has indicated that discrepancies between the data in both systems are common, despite the legal requirement for budget users to implement a monthly reconciliation. The TSA has increased control over budget users' expenditures considerably and decreased liquidity costs since it came into operation in 2002. The system checks for payments automatically against available appropriations and monthly apportionments (of the appropriations) as well as reported commitments. It is further supported by controls by treasury staff, but needs further control support by the budget users. Internal financial procedures and safeguards are the responsibility of the budget user's manager and her delegated financial officers. Currently, the MOF provides guidance on financial management procedures to the budget institutions, but should enforce more strictly a penalty regime for transgressions of laws and regulations. The accounting system of the central government does not directly register receivables and payments due. Arrears are reported separately to the MOF. ${ }^{22}$

\section{Cash management practices are effective, but lack sophistication and} currently are not well-integrated with debt management. The treasury requires budget users to provide annual cash plans, which are updated in consultation with the users on a quarterly basis. The quarterly plans are broken down in monthly apportionments on a line-item basis. This tight control makes regular adjustment of cash apportionment necessary. Cash management is now able to forecast cash usage on a monthly (and even weekly or daily) basis quite accurately, but day-to-day volatility is still high, making a higher-than-desirable cash surplus necessary. The debt issuance calendar is developed by the PDMD with government cash forecasts in mind, but the extent of coordination

\footnotetext{
${ }^{22}$ At end-2004, outstanding arrears of the central government totaled 309 million denars $(0.1$ percent of GDP).
} 
between debt and liquidity management still seems somewhat limited. Cash management has not been problematic in recent months given significant cash surpluses, in turn partially caused by the conscious decision to borrow more than necessary for deficit and/or refinancing purposes, so that the government could continue to develop further the domestic government securities market.

\section{Internal audit capabilities and processes are in the early stages of}

development. The central government has taken the important step to enact the Law on Internal Audit, which prescribes the need for establishing internal audit units within the central government, EBFs, local governments, and other parts of the public sector. The hiring of internal auditors and the setting up of internal audit units by public sector entities has only begun in earnest in 2004. The department of Central Internal Audit (CIA) has been set up within the MOF to provide training and disseminate standards and best work practices for internal audit units. It is too early to indicate the effectiveness of the internal audit process, even at the central government level, where the roll-out has progressed furthest. Strengthening auditing efforts in the public sector is of utmost importance in the coming years. To maximize scarce resources, internal audit activities should be coordinated with the SAO, taking due regard of the independence of the latter institution. Also, the CIA could report to the minister of finance and to the government on a regular basis on the common findings of internal auditors across the public sector, as internal auditors are required to copy for information their reports to the management of the CIA.

\section{Legislation on public procurement has been upgraded to EU standards, but} concerns remain on implementation. The Procurement Law enacted in 2004 provides a very solid basis for open and competitive procurement practices. However, the SAO and independent sources report on instances where assigned officials do not follow regulations appropriately, either by lack of training or knowingly, lack of qualified and independent experts, and misuse of emergency or other special provisions. Procurement processes are audited on a regular basis by the SAO. ${ }^{23}$

\section{Civil service employment procedures are clear, but few instances of discretionary appointments and postings occur. Under the Law on Civil Service} passed in 2000, the Civil Service Agency (CSA) is an independent body enforcing rules and regulations on civil service applications, qualification exams, screening, appointments, and postings. All government bodies submit employment needs to the CSA which, as an independent government body, implements and develops policies related to selection, employment and termination of employment, salaries and allowances, assessment, classification and description of positions and disciplinary liability of civil servants. While the CSA oversees the screening and shortlisting of applicants, senior officials (usually the secretary general) of the concerned government bodies make the final appointment decision, which are not publicly announced. In its current operations and strategic

\footnotetext{
23 The SAO has indicated that weaknesses in procurement practices have so far referred to the implementation of the law that applied before 2004. One of the basic legal obligations of the SAO, when carrying out audit at entities envisaged in the SAO Annual Program, is to evaluate the earmarked and legal utilization of resources, with special emphasis on the manner of implementation of public procurement, the earmarked utilization of funds and everything that is related to the public procurements at the entity, from the aspect of procedures. However, the MOF controls and supervises the application of the law.
} 
planning, the CSA envisages activities focused on the improvement of the legal framework with a view to greater application of the principle of merit as the basic criterion for employment and consistent implementation of the principle of adequate and equitable representation of community members in the government administration.

\section{Clarity of internal control and independence of tax administration}

36. The tax administration is currently strengthening internal monitoring and control mechanisms. In recent years, the PRO has undergone a number of organizational changes. The head office has created an internal audit department with two units:

(i) internal auditing and internal control systems compliance; and (ii) financial auditing, review of operations, and information technology. Customs has procured and now uses software and hardware for an integrated customs information system (MAKCIS) for which it has also carried out an extensive personnel training program. These measures have to a certain extent already strengthened customs administration substantially. However, other revenue collection agencies lag in automation and modern technology, as well as internal audit processes. There is no systematic basis for requesting advance tax liability, although tax officials tend to provide assistance on a case-by-case basis.

\section{Tax administration officials are given legal protection from political}

interference. The system for protecting the tax administration against political influence is based on the provisions of the Law on Civil Servants and the Law on Corruption Prevention. The protection is based on and reflected in the system of working posts established according to the type and level of education and the required working experience, level of expertise and professionalism, which is monitored and assessed on an annual basis. Also, the Law on Corruption Prevention is aimed at preventing political influence during selection, appointment, and dismissal of persons in managerial positions. The PRO and Customs do not control their overall expenditure envelopes, which are proposed by the MOF and approved by parliament, but once the budget is passed, they have de facto authority to reallocate expenditures between line items. In addition, if own-revenue is higher than expected, MOF approval can be sought to increase spending.

\section{Accounting and reporting on budget execution}

38. The treasury accounting system is capable of producing accurate in-year reports on central government budget outturns. EBFs have been integrated into the TSA since 2004, and local governments since 2005. Consolidated as well as other formats of fiscal reporting on the central government are available on a daily basis in the MOF. However, monthly budget outturn figures are placed on the webpage of the MOF and published in the MOF's monthly bulletin with considerable delays. Data on central government arrears are not provided through the treasury system but rather through monthly reporting of budget users. For local governments, end-2004 data on arrears have recently been collected through a special data reconciliation exercise between information from the municipalities and creditors.

39. Regular fiscal reporting covers the central government and the EBFs, while local governments are consolidated with them only on a yearly basis. All layers of the general government use the same chart of accounts, which makes the consolidation possible. However, a significant part of expenditure by the HIF is currently classified as transfers for medical services, shedding little light on the actual use of funds.

Expenditure, revenue, and fiscal balance data are consolidated for the general government 
as are balance sheets. The latter, however, are not included in the final account of the government. Fiscal data include foreign-financed expenditure (through loans and grants), and expenditure from own-revenue sources (of budget users and other entities). Grants-inkind are not reported on the budget documentation.

40. Parliament receives a timely mid-year report on budget execution This midyear report is sent to parliament in the second half of July and contains information on expenditure, revenue, and the fiscal balance of the central government and on the incurrence of debt during the year. Reporting will be extended to the general government in 2006 since both the EBFs and local governments are now included in the TSA. As described above, the MOF publishes budget execution data on its webpage and monthly bulletin.

41. The final accounts of the central government are audited by the SAO but not always sent to parliament within six months of the end of the fiscal year. According to the law, the final accounts of the central government should be sent to the SAO by end-February and then sent to parliament by end-June of the year subsequent to the fiscal year of the final accounts. Performance in keeping with the required timetable is still imperfect, but nevertheless improving. The 2001 final accounts were sent to parliament in December 2002, while the 2003 final accounts were sent in January 2005. But the 2004 final accounts were presented to parliament within the legally-mandated timetable. The accounts of the EBFs and local governments are included in the final accounts of the central government and sent to parliament for information. The MOF publishes consolidated fiscal data on the central government, EBFs, and local governments in the State Gazette no later than October 15.

\section{Results-oriented budgeting and reporting}

42. The objectives and expected results from government activities are so far discussed in the budget documents only in general terms. Program budgeting has been introduced only recently, using policy implementation activities as the main identifier of programs. The linkage of programs to policy objectives has not been done systematically, nor has the linkage of programs to output and outcome indicators, let alone setting targets for these. International experience indicates that using performance information in the budget process is extremely difficult and should not be rushed. Thus, the main objective for the coming years should be to improve the present program structure and to develop a methodology for medium-term forward estimates, embedding the program structure in a medium-term expenditure framework.

\section{Public Availability of Information}

43. Fiscal information is comprehensive and available to the public often with considerable lags, but there is a clear commitment to provide essential information at scheduled times. Budget, annual accounts, and the mid-year budget execution review are produced in a timely manner. However, other sources that could provide more immediate information on budget execution (available from the treasury and published on the MOF's webpage and monthly bulletin) are updated with some delay. Consolidation of the general government takes place only annually, and this information is provided somewhat late to the general public. Improvements in the provision of consolidated data can be expected in the near term due to the inclusion of EBFs and local governments in the TSA. 


\section{The coverage and quality of budget documents}

\section{The budget documents cover central government fiscal activities} comprehensively, but provide no data on the general government; defense expenditures are reported comprehensively in the budget at the same level of detail as for other budget users. Fiscal data are presented in the budget in various classification formats, including economic and functional formats, a combination of organizational and programmatic formats, and programmatic and economic formats. The budget sent to parliament contains the following sections: (i) the budget memorandum, which is essentially a commentary by the minister of finance on the fiscal and budget policies for the coming year; (ii) the budget proposal, containing both details on the macroeconomic framework, strategic priorities, and program implementation, as well as a description of budget expenditure according to various classifications; and (iii) the draft law on budget execution, which provides details on the government's plans for suballocations in various budgets. In the budget memorandum only a summary overview of the budget is presented at a very aggregated economic classification. Key individual spending increases are indicated in the explanatory text. In the 2005 Budget, for the first time the budget memorandum contained an in-depth discussion of government and line ministry programs, which signals an important improvement in transparency. However, the program discussion in the budget memorandum should be directly linked to expenditure data for their respective programs, including medium-term expenditure estimates. Also, the discussion should include organizational and functional overviews of expenditure. The discussion of capital expenditure should be carried out in more detail and, if possible, be linked to programs of (first-level) spending units. The budget memorandum can be downloaded from http://www.finance.gov.mk/gb/, but supporting documents and annexes are not available there.

\section{Past and forecast fiscal data in the budget}

45. The budget document discloses the main fiscal aggregates for two years prior and medium-term projections for two years beyond the budget year, but the latter is not presented in the main budget memorandum. The analysis in the budget document of the past budget vis-à-vis actual budget outturns needs to be expanded. The budget memorandum itself does not provide indicative budgetary estimates for the next two years nor a descriptive analysis. This is only presented in the fiscal strategy document and should be reiterated in the budget document. The forward estimates should, in the coming years, be made available in more detail. The nature of the budget programs suggests that they should be presented in a medium-term context.

\section{Budget treatment of off-budget fiscal activity}

46. Statements on tax expenditures and contingent liabilities are not included in the budget nor in the final accounts documents. However, sovereign guarantees require adoption by parliament of an individual guarantee law. Other contingent liabilities do not seem to be particularly large. For example, at end-2004 the government had only two domestic debt guarantees outstanding toward private companies, valued at approximately 1.6 million denars. Currently, there is no reporting on contingent liabilities to parliament nor to the general public, except for debt guarantees that are incorporated into the public debt information. But debt guarantees only enter budget data when provisions are made in the budget to pay off called guarantees. Contingent liabilities will 
be reported in the budget as prescribed in the new Organic Budget Law and will also be included in the semi-annual debt reporting required under the new Public Debt Law.

\section{Quasi-fiscal activities do not appear to be extensive, but they are not} estimated and, therefore, not included in the budget documents. As indicated above, quasi-fiscal activities of the SOEs are likely to have been reduced to small amounts due to the process of restructuring of SOEs toward market activities and the rather advanced stage of the privatization process.

\section{Publication of data on debt and financial assets}

48. Provision of information on public debt has recently improved. The MOF now publishes integrated information on public debt, i.e., both external debt - which was previously registered and published by the Central Bank, and domestic debt, on its webpage and in its monthly bulletin. Information is also compiled and published on debt guarantees. ${ }^{24}$ Information and analysis of central and general government gross debt can still be improved, and such analysis should be published as part of the annual reports on the PDMS.

49. Information on government financial assets is not published. Only the debt level and structure of government financial entities are published with the annual budget. The reports on assets and liabilities are submitted to the central registry at the end of each year. Public financial corporations, as mandated by the Law on Public Enterprises, release their income statements and balance sheets to the Budgets and Funds Department of the MOF on a regular (annual) basis; they are also obliged to have their final accounts audited and submit them to a public registry. These data (by entity or in aggregate) are considered by the MOF to be confidential. In general, financial assets and liabilities are assessed on the basis of market prices or market price equivalents.

\section{Commitment to timely publication of fiscal data}

\section{Formal commitments for regular publication of fiscal data and their timing}

are specified in law. The annual budget, the final accounts, and the mid-year budget execution review are published according to a schedule laid down in the Organic Budget Law and the Law on Budget Institution Accounting and Internal Control. More frequent dissemination of budget execution data is not a legal requirement. The MOF prepares a draft annual budget account of central government and submits it to government (by April 30) and, subsequently, to parliament, where it is enacted in regular procedure. Consolidated data on the general government are also made available to the general public, but only $91 / 2$ months after the end of the fiscal year. Reporting on the public sector is not the responsibility of the MOF but rather of the State Statistical Office (SSO). FYR Macedonia participates fully in the IMF's General Data Dissemination System (GDDS).

\footnotetext{
${ }^{24}$ The new Law on Public Debt stipulates an obligation for the MOF to publish debt stock information on its website and in the MOF bulletin. Also, according to the Law, the MOF should prepare and publish an annual and semi-annual report for the implementation of the PDMS.
} 


\section{Assurances of Integrity}

\section{Integrity of data processes}

51. While budget data are not a reliable estimate of outturn, the variance between budgeted and actual outturn of the main fiscal aggregates is presented to parliament and to the general public. Based on an aggregated economic classification of expenditure in 6 categories, forecast variances deteriorated from an average of 9.4 percent in 2002 to 13.1 percent in 2004. For revenue, subdivided in six categories, forecast variances deteriorated from 21.9 percent to 24.1 percent. These variances are large compared to international experience and could indicate that either revenue and expenditure projections are not well developed or that supplementary budgets are a standard feature of the budgetary process. The differences between budgeted amounts and the budget outturn are presented (but not fully discussed) in the budget documents and the annual accounts. For transparency and accountability purposes, this is clearly an area in need of improvement. Supplementary budgets are sizeable and used most often once and in rare cases twice per year. Contingency spending is limited by law to 3 percent of budget outlays. Parliament is informed on the use of reserve appropriations through supplementary budgets and the annual account.

52. Statements on accounting basis and policy are not specified in the budget and final accounts documents, but are detailed in publicly available documents. As indicated previously, the accounting system is cash-commitment based. The chart of accounts is well developed, with the economic classification nomenclature conforming to the GFS 2001 system, and the functional classification being aligned to the UN's COFOG classification. The accounting system for general government is set out in the Law on Budget Institution Accounting and Internal Control. The MOF has developed an accompanying manual to this Law, to provide guidance on accounting practices for budget users. Financial reporting of budget users is in accordance with the public sector international accounting standards for financial reporting under the cash basis accounting system, which was issued by the public sector committee of the International Federation of Accountants (IFAC). Thus, accounting standards match international standards, although actual practice is not always in line with these standards according to SAO reports. So far, there is no plan to move to a system of accrual accounting. Nonetheless, as a first step, the treasury should work toward incorporating accounts receivable and accounts payable in the treasury accounting system.

53. The process of accounts reconciliation and fiscal reporting is effective. Budget users keep separate accounting records and underlying documents as part of their financial administration. Treasury accounting reports based on transactions through the TSA are reconciled with those accounting records frequently. According to the law, reconciliation takes place at least monthly. Budget users are not allowed to have bank accounts outside the TSA. Reconciliation of financing items with treasury data is not an important issue as both are cash based and handled through the TSA. The treasury reconciles accounts of budget users, processes delayed payments, and closes its books within ten days of the end of the fiscal year. 


\section{Independent oversight}

\section{External audit is independent from the executive branch, and its mandate} covers all public sector activities. The independent audit of the budget, budget users, EBFs, local government, political parties, agencies, the NBRM, SOEs, and expenditures funded by external loans and donations, and of any entity receiving significant public funds, falls under the mandate of the SAO, as specified in the Law on the State Audit. Annual audits are mandatory for the central and local governments, SOEs, and political parties. The head of the SAO, the general state auditor, is appointed to and removed from office by parliament. The SAO reports to parliament on its findings through an annual report and subsequent discussion with parliament. The work of the SAO focuses primarily on the legality and authorization of expenditure and revenue, as well as compliance with processes and accounting standards. Also, the SAO has begun looking at the effectiveness and efficiency of government activities. For this purpose, the SAO has recently set up a new performance audit department. The activities of this unit are still at an early stage of development.

55. Strengthening of audit capacity is required. The quality of the work of the SAO is generally well regarded, but funding for its activities is seen as very limited. International donors, NGOs, and the budget committee of parliament have indicated their overall satisfaction with the work of the SAO. Its procedures and standards are based on those of the International Association of Supreme Audit Offices (INTOSAI). Given budgetary and staffing constraints, the scope and depth of auditing activities seems to be less than desirable. For its very broad mandate, the SAO employs only 56 auditors. Also, the SAO has no budgetary autonomy. The special position of the SAO would seem to warrant an independent review of the adequacy of its budget on a regular basis. This would dispel perceptions that the role of the SAO in auditing the executive branch might play any part in its budget allocation. Of course, such an independent review should place the budgetary needs of the SAO in the context of the scarcity of resources in the public sector as a whole.

56. The SAO is required to send its annual report on activities and findings to parliament by September 30, and it has generally fulfilled this requirement. In recent years, the SAO annual report was usually published on that day. However, parliament requested the 2004 report to be sent by March 31, 2005, which permitted a more focused discussion away from the discussions on the new budget. The submission of the SAO annual report should ideally be coordinated with the presentation of the audited final account of general government by the MOF, to provide the necessary background to the former.

\section{The budget committee of parliament discusses external audit reports} intensively, but parliament and the executive do not systematically follow up on audit findings. Before being sent to parliament, the executive has the opportunity to respond to the SAO findings. The SAO can incorporate factual corrections, but otherwise would publish the reaction of the government in its report. The discussion on the SAO's annual report is done through the budget committee of parliament. The discussion is usually not elevated to the full parliament and does not usually lead to the passing of motions. Several sources have commented on the perceived lack of follow-up on SAO findings and recommendations. However, in the annual report, the SAO does track responses and corrective actions taken by audited entities. The general state auditor has 
indicated that, from a long-term perspective, the activities of the SAO seem to be having an impact on the quality of the public sector's financial management.

58. External scrutiny of macroeconomic assumptions and projections is allowed but its usefulness is limited due to capacity constraints. Macroeconomic forecast are not based on an econometric model, which would be difficult to calibrate due to significant changes in the structure of the economy. Instead, macroeconomic projections are made primarily by using recent historic data (trends) and surveys on (future) economic activity. These projections and the assumptions behind them are discussed with the NBRM and the IMF, and are published in the fiscal strategy document. Currently, local banks and universities do not seem to have the technical capability to conduct independent macroeconomic forecasts.

59. The national statistics office is given legislative assurances of independence. The national accounts are compiled and disseminated by the State Statistical Office (SSO). The main legal basis for the compilation of the national accounts is the Act on the State Statistics (adopted by parliament in 1997). The responsibility of the SSO for the compilation of the national accounts is clearly defined in the program of statistical research which, according to the law, is prepared by the SSO under the guidance of the Statistical Council of the Republic of Macedonia and submitted for approval to the government. This program lists all the official statistics to be compiled by the SSO and the other authorized bodies. Despite the significant improvements in the operations of the SSO from the aspect of collection and availability of data, further efforts are still required to ensuring quality and timely data, which are necessary for the proper analysis of macroeconomic trends. For example, improvements in the system of national accounts need to be made (e.g., the completion of the expenditure side of the GDP), as well as in the calculation of the basic inflation rate, labor productivity, costs per unit of output.

\section{IMF STAFF COMMENTARY}

\section{FYR Macedonia currently meets the requirements of the fiscal transparency} code in several key areas:

- The allocation of responsibilities among different levels of government has been generally well defined; intergovernmental fiscal relations have been established and tax assignments as well as revenue sharing agreements are clearly set by law, but the ongoing decentralization process, particularly related to the devolution of expenditure responsibilities to local governments and borrowing by local governments, must be carefully monitored and underpinned by improved capacity at the local level.

- The NBRM has operational independence from the government to conduct monetary policy and is barred from financing the government.

- Information on public and publicly-guaranteed debt is regularly published.

- The legal framework for the management of public funds is clear and comprehensive with regard to the budget process and responsibilities. 
- The annual budget process is transparent and the budget presentation is rapidly moving toward international good practice; the chart of accounts consists of an economic, functional, organizational, and program classification; the classification used for determining appropriations has source of funding, organizational unit, program, sub-program, and economic item levels.

- Budget preparation has a strategic phase, where the main parameters for fiscal policy are determined and indicative ceilings for expenditure areas are set.

- The introduction of program budgeting with the 2005 budget (together with a description of programs in the budget document) has provided much better transparency of the government expenditure plans.

- The treasury accounting system is capable of producing accurate and frequent in-year reports on central government budget outturns; EBFs and local governments have been integrated into the TSA.

- The legislative basis for taxation is generally clear and comprehensive, and legislation in the areas of value-added tax and customs duties are being harmonized with EU practices.

- Tax administration officials are given legal protection from political interference.

- The SAO is independent from the executive branch and its mandate covers all public sector activities, such as the budget, budget users, EBFs, local governments, political parties, agencies, the NBRM, SOEs, and expenditure funded by external loans and donations, and of any entity receiving significant public funds.

- The SAO is given legislative assurance of independence.

61. To improve fiscal transparency even further, FYR Macedonia needs concentrate efforts on: (i) compiling and providing regularly information on fiscal risks, contingent liabilities, and tax expenditure; (ii) improving the reporting on the activities of SOEs; (iii) revamping and making the PIP process more useful to the budget process; and (iv) enhancing significantly internal and external control mechanisms. More specifically:

- Information on fiscal risks, contingent liabilities, and tax expenditures should be compiled regularly and provided in budget, budget execution, and final accounts documents.

- Comprehensive data on state financial assets should be compiled and published regularly.

- Reporting on SOEs and state assets should be strengthened; in particular, overall policy objectives of the government and the specific stance toward individual SOEs need to be clearly presented, the (shared) responsibility for the management of state assets within the government needs to be better defined, and the financial statements of SOEs should be published regularly. 
- The nomination process for board members of SOEs, funds, agencies, and other institutions receiving substantial public resources should be made more transparent; as a minimum, the names of board members and their remuneration should be published.

- There should be a clear provision in law for market-determined interest payments on government deposits held at the central bank; however, this should be accompanied by further improvements in the treasury's cash management capabilities, to reduce the need for large balances to be held in the TSA and, therefore, minimize the interest cost to the NBRM; the level of fees charged by the NBRM for services to the treasury might also need to be reviewed, to offset partially the cost of paying marketdetermined interest.

- While the fiscal strategy document contains clear medium-term forecasts and analysis of macrofiscal conditions and policy choices of the government, these should also be included and updated in the budget memorandum.

- As the fiscal strategy document has become increasingly important for budget preparation during the course of the year, consideration should be given to sending this document to parliament for discussion.

- The strategic phase of budget preparation in the coming years should be expanded to a system of more detailed and accurate medium-term budget estimates, which could be used for making informed decisions on a medium-term expenditure framework; this would imply developing in the MOF a forward estimates methodology, to enable other ministries and agencies to forecast line-item expenditure.

- In the coming years, the fiscal and debt sustainability as well as the sensitivity analysis that are prepared as part of the public debt management strategy should be presented in an integrated way with the fiscal strategy and budget documents.

- The timeliness and frequency of budget execution reporting to parliament and the general public should be improved; budget execution reports to parliament should provide more economic and policy explanation, and include consolidated figures for the general government; budget execution reports posted on the MOF's webpage should be kept up to date.

- The timeline for budget preparation should include an extended period for parliament to discuss the budget.

- A concrete plan for investment projects and specification of program activities should be presented with the budget document, implying that most of the planning activities in the Budget Execution Law should be already determined with the submission of the annual budget to parliament.

- The program structure of the budget needs to be refined further in the coming years, to be better aligned with line-ministry policy objectives rather than with organizational structures.

- Managerial flexibility in reassigning expenditure during the budget year on the authority of the MOF (i.e., power of virement) should be tempered by the requirement that budget expenditure and its purpose be approved by parliament; virement limits 
should be specified in law and relatively narrow, to enhance transparency and protect the authorization function of parliament (however, the transition to the new program budgeting would call for temporarily higher virement limits, but inter-program virement should be limited to 5 percent for current expenditure line items and 10 percent for capital expenditure).

- Hard expenditure ceilings early in the budget process should be set transparently on the basis of a well-designed strategic (re)allocation phase and based on adequate insight into medium-term budgetary developments and needs of line ministries; before this capacity is developed, expenditure ceilings should only be indicative, to avoid promoting incrementalism in budget preparation.

- A resolution mechanism between the objectives of fiscal policy and the legal framework of entitlement programs managed through EBFs should be developed.

- The PIP process should be brought forward in time, to be better connected to the budget process; in addition, the PIP process should be integrated to the budget program methodology in that public investment should be clearly aligned with government policies and programs.

- Before being considered by the MOF and government, investment projects should include, together with their financing needs during execution, annual projections for current and capital expenditure needs once the project is completed.

- A system of tracking the expenditure implications of new initiatives should be developed in the MOF, and the budget memorandum should provide detailed overviews of new expenditure initiatives.

- The TSA should include reporting on receivables or payments due of both budget users and local governments.

- Transgressions of internal control measures at spending units should be actively monitored and sanctioned by the MOF; the central internal audit department of the MOF could play a coordinating role between the treasury and line ministry internal auditors.

- Internal audit capabilities and processes are in the early stages of development and should be strongly supported; the central government has taken the important step to enact the Law on Internal Audit, which prescribes the need for establishing internal audit units within the central government, EBFs, local governments, and other parts of the public sector, but the hiring and training of internal auditors and the setting up of internal audit units have only begun in earnest in 2004 .

- Ethical standards for civil servants should be enforced with more vigor, and should be one of the key issues to be taken up by the new internal audit function in line ministries and agencies.

- The quality of the work of the SAO is generally well regarded, but funding for its activities is insufficient to carry out effectively its very broad mandate and should be increased. 
- Joint presentation to parliament of the SAO annual report and the general government's final accounts should be targeted for June.

- While the budget committee of parliament discusses external audit annual reports, parliament and the executive branch do not systematically follow-up on its findings and recommendations; follow-up on the recommendations of the SAO should be significantly improved. 


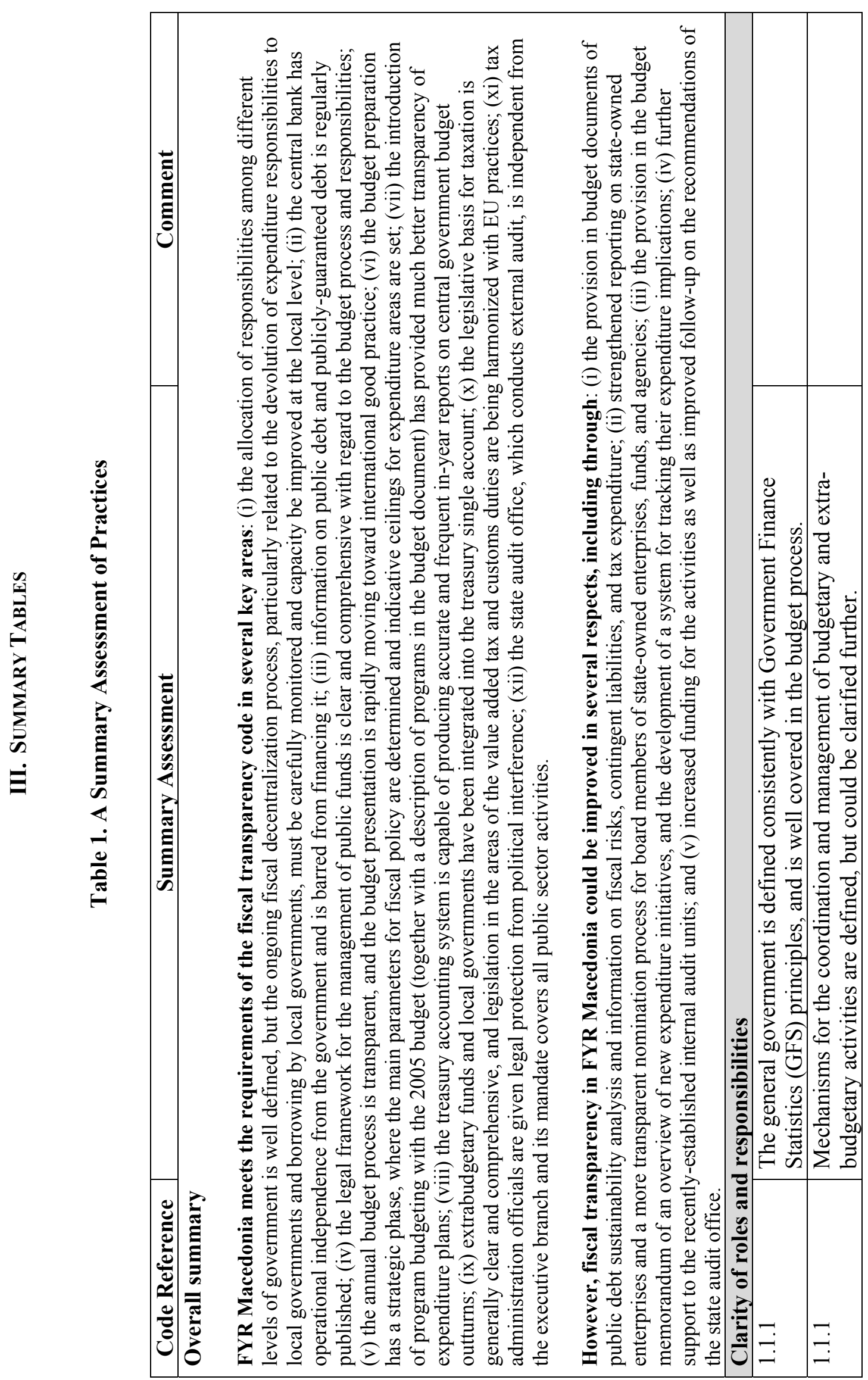




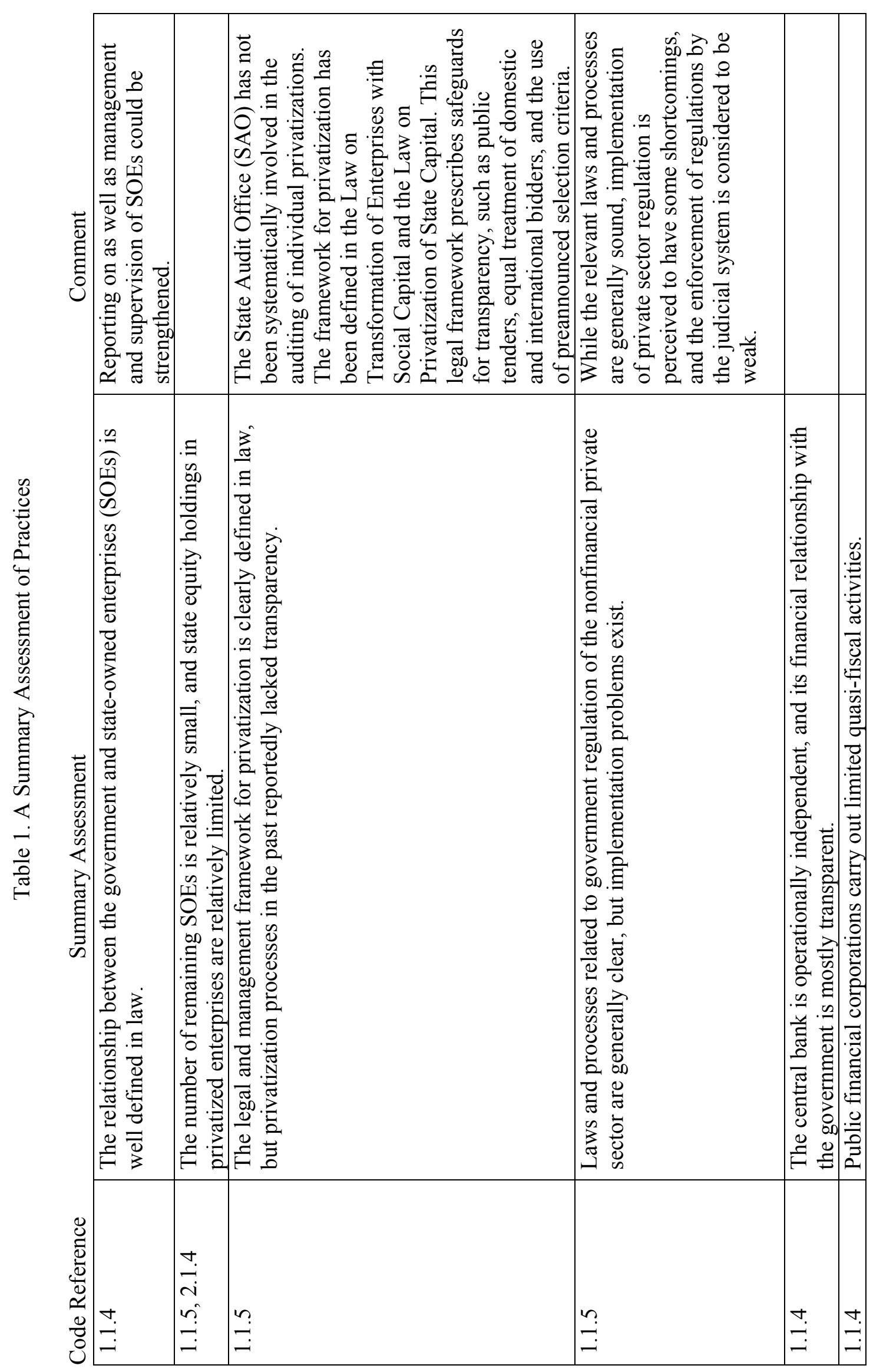




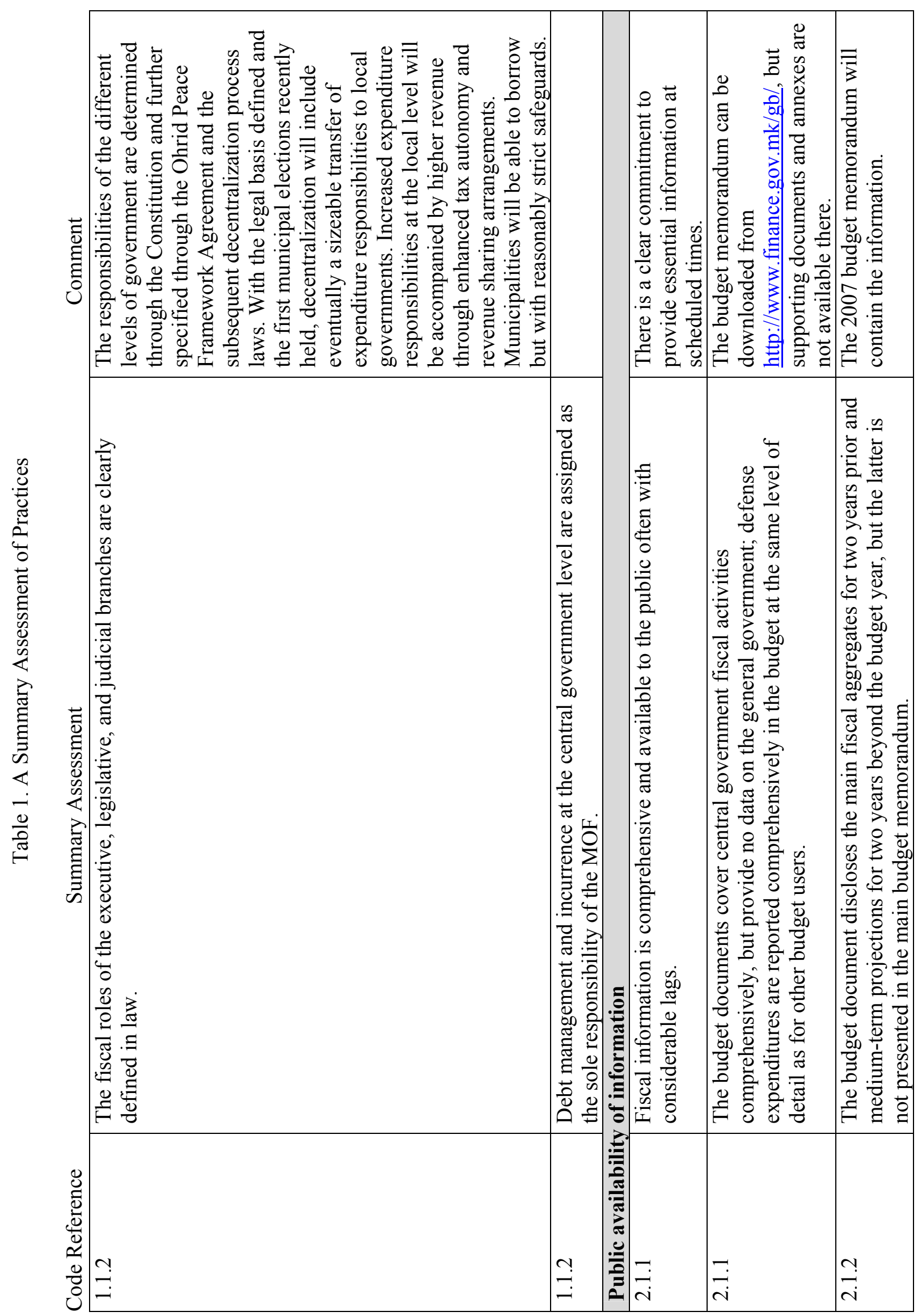




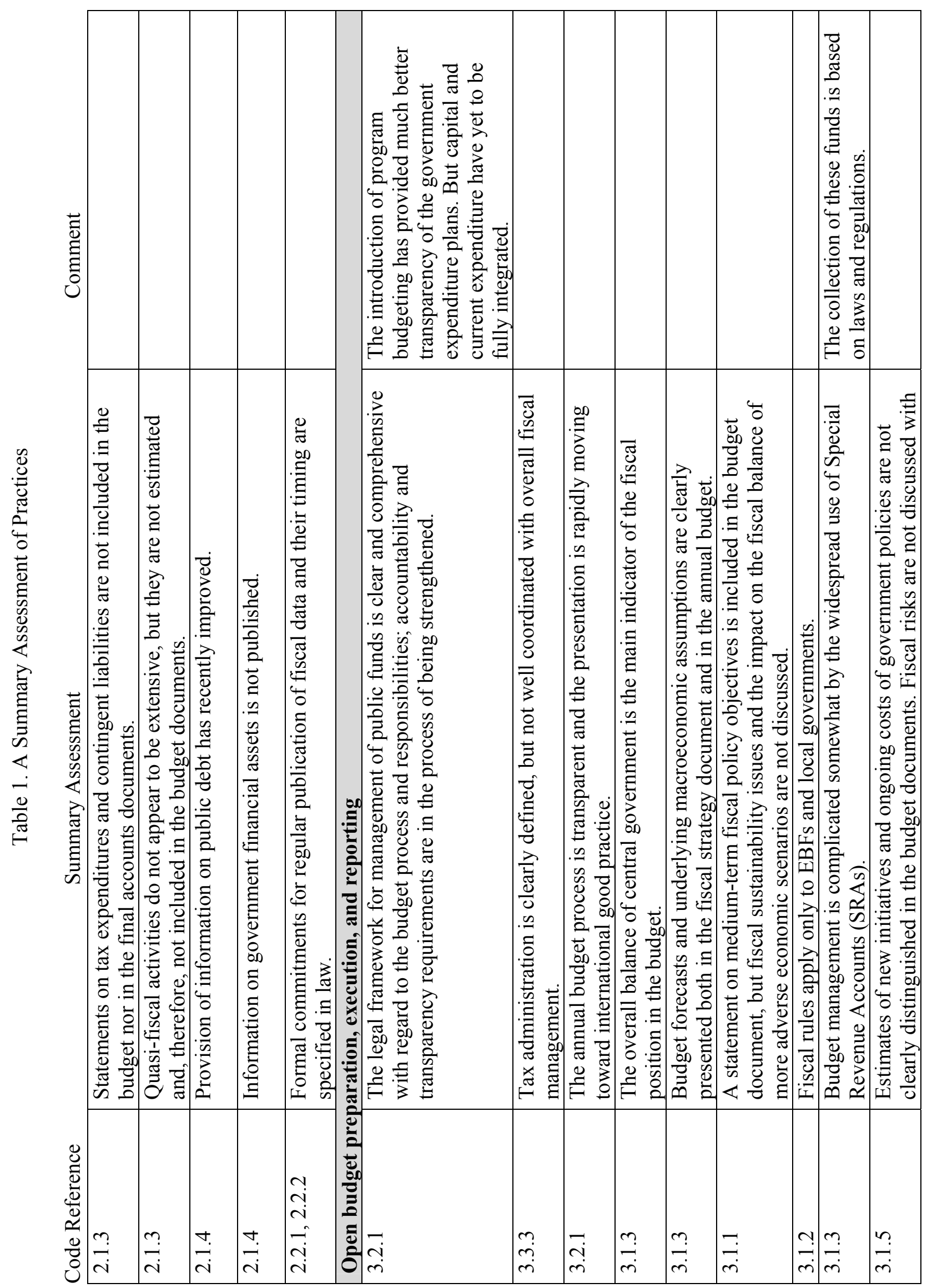




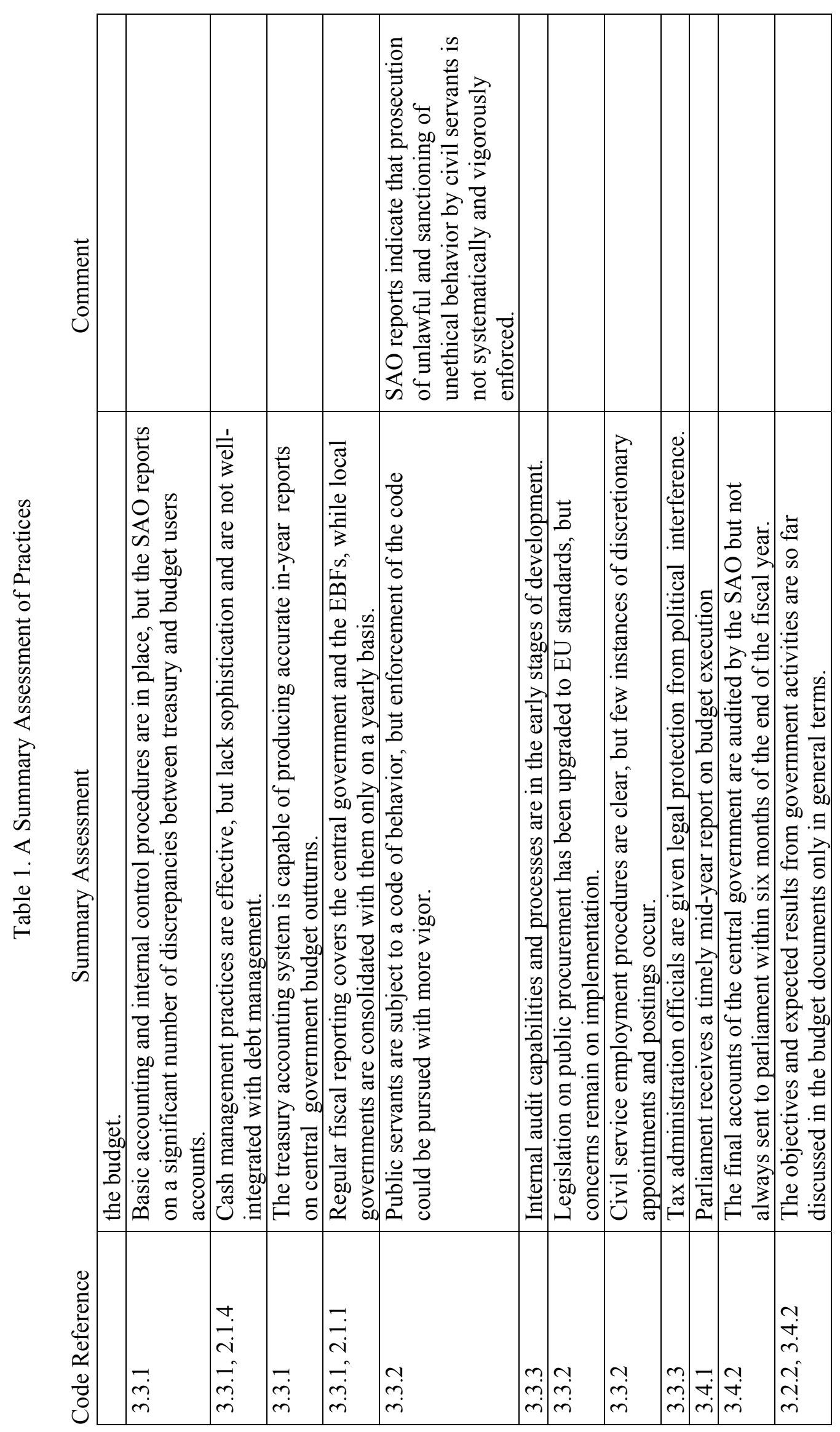




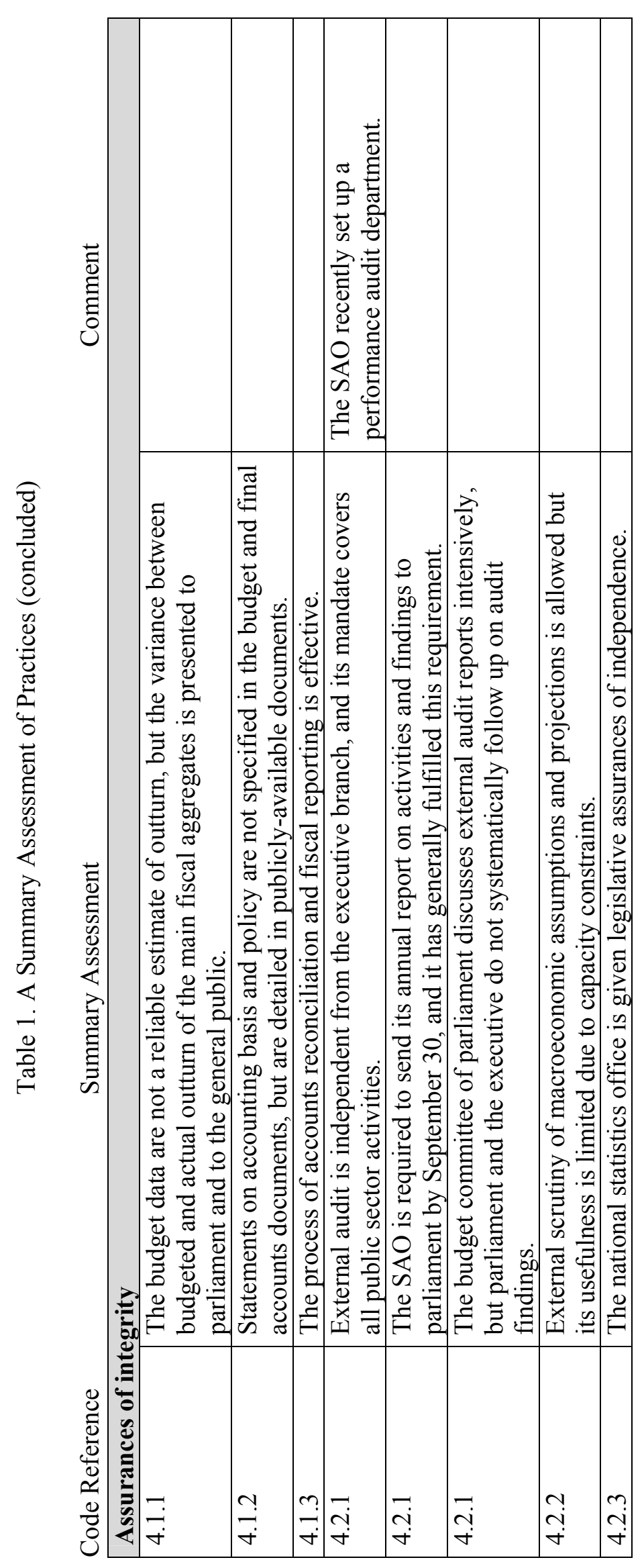

